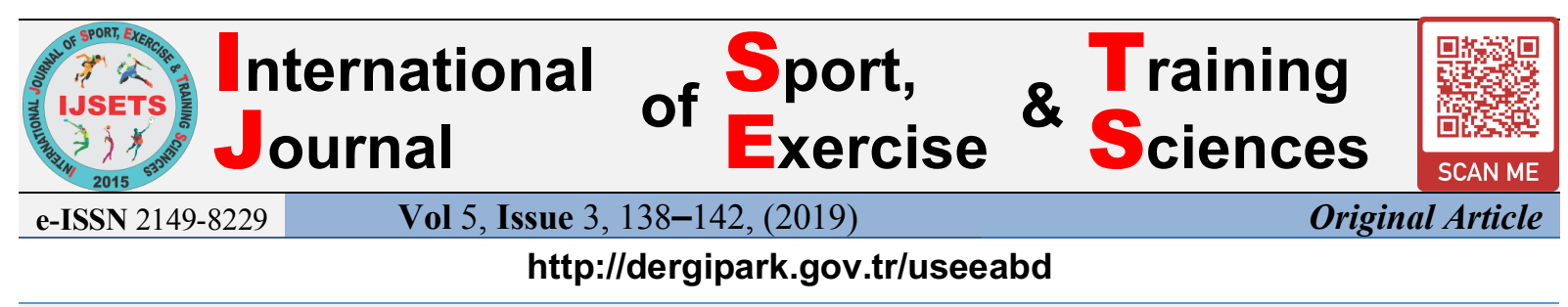

\title{
The Effect of Narcissism and Neuroticism on Physical Education and Sports Teacher Candidates of Real and Self-Estimated Exam Grades
}

\author{
Nihal DAL ${ }^{1}$
}

\begin{abstract}
Aim: The present study aimed to investigate the joint effect of narcissism and neuroticism on physical education teacher candidates' real and self-estimated exam grades.

Methods: The sample included 60 (20 female) first-year physical education teacher candidates. Before the educational psychology visa exam, participants completed measures of narcissism and neuroticism. Immediately after the exam, participants reported their expected exam grades. Results: Results of the correlation analysis indicated that narcissism was positively and significantly associated with the deviation of the self-estimated exam grade from the real exam grade, which means that narcissistic individuals may tend to overestimate their exam grades. Regression analyses also confirmed that narcissism is a significant predictor of the deviation of the self-estimated exam grade from the real exam grade. A two-way analysis of variance further demonstrated that narcissistic individuals self-estimated exam grades showed a higher deviation from the real exam grades than their non-narcissistic counterparts.

Conclusion: Narcissistic individuals may have a predisposition to overestimate their exam grades.
\end{abstract}

Keywords

\section{Beden Ĕ̆itimi ve Spor Öğretmeni Adaylarında Narsisizm ve Nörotisizmin Gerçek ve Tahmin Edilen Ders Notuna Etkisi}

\begin{abstract}
Öz
Amaç: Bu çalışmanın amacı, beden eğitimi ve spor öğretmeni adaylarında narsisizm ve duygusal tutarsızlığın gerçek ve tahmin edilen sınav notuna etkisini incelemektir.

Metod: Araştırmaya 20si kadın toplam 60 beden eğitimi öğretmeni adayı katılmıştır. Katılımcılar eğitim psikolojisi vize sınavı öncesinde narsisizm ve nörotisizm ölçümlerini tamamlamışlardır. Katılımcılar sinavdan hemen sonra bekledikleri notu da rapor etmişlerdir.

Bulgular: Korelasyon analizi sonuçları narsisizmin tahmin edilen notun gerçek nottan sapma miktarı ile pozitif yönde anamlı ilişki olduğunu göstermiştir. Bu sonuçlar narsistlerin bekledikleri notu abartma eğiliminde olduklarına işaret etmiştir. Regresyon analizi sonuçları da narsisizmin beklenilen notun gerçek nottan sapma miktarını anlamlı olarak öngörebildiğini göstermiştir. İki yönlü varyans analizi sonuçlarına göre, yüksek narsisizme sahip bireylerin tahmin ettikleri sınav notunun gerçek nottan daha büyük bir sapma gösterdiği saptanmıştır. Sonuçlar: Narsistler sınavdan bekledikleri notu abartmaya eğilimli olabilir.
\end{abstract}

Anahtar Kelimeler Narsisizm,

Nörotisizm,

Sinav notu,

\section{INTRODUCTION}

Personality traits, especially within the Big Five model have consistently been recognized as the robust predictors of academic success at school (Ridgell \& Lounsbury, 2004; Tok \& Morali, 2009). These studies provided evidence to suggest that among the Big Five personality traits such as conscientiousness, openness to experience, and neuroticism may have the potential to explain variation in academic success which conceptualized by grade point average (GPA). In addition to academic success based on GPA, personality traits have also been found to have predictive power in relation to the success of the academic examination.

Although there is a considerable relationship between GPA performance and personality traits, researchers paid less attention, whether narrower or lower-level personality traits in addition to supertraits may be associated with overall academic success specifically with academic examination. Further, previous studies focused mainly on theoretical based academic fields such as science, literature, and business, and ignored students' academic success requiring both practical and theoretical skills such as physical education and sports. Therefore, there is a clear need to understand whether a narrower personality trait (e.g., narcissism) and together with the super trait neuroticism may be associated with success in a particular academic examination. Further, it is not clear whether students' expected academic success immediately after an academic examination is associated with specific psychological qualities or not. 
Before presenting a theoretical background to assume a link between narcissism and success in an academic examination, it is of importance to make a distinction between non-clinical and clinical narcissism. In this respect, clinical narcissism, which is defined as "a pervasive pattern of grandiosity, need for admiration, and a lack of empathy" (American Psychiatric Association, 2000, p. 714). On the other hand, "sub-clinical narcissism is viewed as a personality trait that every healthy individual may have at varying degrees" (American Psychiatric Association, 2000, p. 714).

The present study focuses on sub-clinical or normal narcissism as a personality trait that every healthy individual may have at a varying level. The main reason for the selection of narcissism as a possible antecedent of both actual and expected academic examination success is the increase of narcissism among college students and narcissist students' sense of entitlement and inflated expectations. Scientific evidence suggests that sub-clinical narcissist may have a hugely positive or inflated sense of self (American Psychiatric Association, 2000; Millon, \& Davis, 1996). Narcissist also considers themselves as superior to others (Gabriel, Critelli, \& Ee, 1994). Despite the narcissist relatively high self-confidence and their belief that they are better performers than others, the scientific literature does not provide secure and consistent evidence for a positive association between narcissism and performance (Gabriel, Critelli \& Ee, 1994; John \& Robins, 1994). Hence, it seems that narcissistic personality trait may not be associated with success in a particular academic examination, mainly due to the narcissists' predisposition to an inflated expectation of success from an academic examination. On the contrary, narcissistic personality trait may be linked with a higher level of self-estimated success in a particular academic examination because of their tendency to inflate their abilities. Previously, Greenberger, Lessard, Chen, \& Farruggia 2008 who found that narcissist students believe that their professor should lend them his/her course notes if they ask for them provided evidence for this argument.

Another personality trait that can be antecedent of the success in a particular academic examination is neuroticism that is an individual's emotional stability and tendency to experience negative emotions (Miller \& Campbell, 2008). As the neuroticism includes features such as a lower level of confidence, a higher level of arousal and a predisposition to anxiety and stress (Barlow, Woodman, Gorgulu, \& Voyzey, 2016; Somer, Korkmaz \& Tatar, 2004), neuroticism may have a potential to make a negative impact on success in a particular academic examination. Moreover, due to the high neuroticism students' lower level of self-confidence; neurotic students possibly underestimate their level of success immediately after an academic examination.

The present study sought to explore whether narcissism and neuroticism may have the ability to predict success in a particular examination in physical education teacher candidates. In the light of research results cited above, as well as anecdotal evidence, it was hypothesized that narcissism should not be associated with success in an academic examination. However, narcissism should be related to a higher level of self-estimated examination grade. Neuroticism should be negatively correlated to success in academic examination, but unrelated to self-estimated examination grade.

\section{METHOD}

\section{Participants}

The sample consisted of 60 (20 female,) physical education and sports teacher candidates, ranging in age from 18 to 22 , (Mage $=21.4 ; S D=2.7)$ The local ethics committee approved the study protocol. Participants provided informed consent approved by the local ethics committee (20.478.486). All procedure was executed following the latest version of the Helsinki Declaration.

\section{Materials}

The Narcissistic Personality Inventory (NPI-16): In order to measure narcissistic personality trait, The Narcissistic Personality Inventory (NPI-16) developed by Raskin \& Terry (1988) and adapted into Turkish by Atay (2009) was employed. The NPI has 16 items, and each item includes a narcissistic statement and a non-narcissistic statement in a forced-choice format. NPI-16 scores can range from 0 to 16.

Neuroticism In order to assess neuroticism, the short form of the Five-Factor Personality Inventory (FFPI) developed by Tatar (2005) was employed. The FFPI is an 85-item personality inventory designed to evaluate the five personality traits of neuroticism, extraversion, and openness to experience, agreeableness, and conscientiousness. Item responses are made using a 5-point Likert format. In this 
study, only the neuroticism subscale of the FFPI was used to determine participants' level of emotional stability.

Procedure: The author personally invited individuals to take part in the study. Participants first responded NPI-16 and the short form of FFPI before Educational Psychology mid-term. After the midterm exam, participants were contacted in person and asked to estimate their exam grade. Lastly, participants' psychometric data obtained immediately before the Educational Psychology mid-term exam then matched self-estimated and real exam grades.

\section{Statistical analysis}

Shapiro-Wilk tests for normality indicated that parameters were normally distributed. In order to analyze the obtained data set, Pearson correlation coefficients were calculated among academic self-efficacy, pre-exam anxiety, real grade, and self-estimated grade. Afterward, regression analysis was conducted to test whether the regression model consisting of narcissism and neuroticism may have the ability to predict the deviation of the self-estimated exam grades from the real exam grades. In order to determine the deviation of the self-estimated exam grades from the real exam grades, participants' real exam grades were dived by estimated exam grades and multiplied by 100. In this way, the deviation of self-expected exam grade from real grade was expressed in percentages. Then, a two-way analysis of variance (ANOVA) was conducted to examine whether the deviation of self-estimated exam grade from the real exam grade differed as a function of narcissism and neuroticism together or not. In this analysis, the percentage change of exam grade was entered to the model as the dependent variables. The independent variables were high-and-low-narcissism with low- and high-neuroticism. Based on a median split of the narcissism (median $=6$ ) and neuroticism (median $=2.6$ ) scores, the sample was grouped as high-and low-narcissism and low- and high- neuroticism groups (for a review see Woodman, Roberts, Hardy, Callow, \& Rogers, 2011).

\section{RESULTS}

Table 1. The relationship among narcissism, neuroticism, real grade, and exam grade

\begin{tabular}{lccccc}
\hline \multicolumn{1}{c}{ Variable names } & Mean \pm SD & $\mathbf{1}$ & $\mathbf{2}$ & $\mathbf{3}$ & $\mathbf{4}$ \\
\hline 1 Narcissism & $6.5 \pm 2.8$ & - & & & \\
\hline 2 Neuroticism & $2.7 \pm 0.06$ & $-0.28^{*}$ & - & & - \\
\hline 3 Real Grade & $49.9 \pm 15.6$ & -0.20 & -0.20 & - & - \\
\hline 4 Expected Grade & $62.5 \pm 13.3$ & 0.15 & -0.21 & $-0.40^{* *}$ & $-0.43^{* *}$ \\
\hline 5 Exam grade chance & $12.6 \pm 15.9$ & $0.32^{* *}$ & 0.02 & $-0.64^{* *}$ &
\end{tabular}

As illustrated in Table 1, the Pearson correlation coefficient indicated a positive and significant correlation narcissism and exam grade change (deviation of self-expected exam grades), which means that as the narcissism scores increase, the deviation of self-expected grades increases too. On the other hand, both narcissism and neuroticism were unrelated to real and self-expected exam grades. Similarly, neuroticism was not related to exam grade change.

Table 2. The predictive power of the narcissism, neuroticism.

\begin{tabular}{lccccc}
\multicolumn{1}{c}{ Independents } & $\mathbf{B}$ & Beta & t & R & $\mathbf{R}^{\mathbf{2}}$ adj \\
\hline Constant & -10.30 & & -0.929 & & 0.10 \\
\hline Narcissism & 2.02 & 0.368 & $2.876^{*}$ \\
\hline Neuroticism & 3.59 & 0.143 & 1.120 & 0.355 & 0.10 \\
\hline * $<.05$ & & & &
\end{tabular}

Based on the significant relationship between narcissism and exam grade change, linear regression analysis with the enter method was conducted to determine whether the regression model consisting of narcissism and neuroticism may have account for the deviation of elf-expected exam grades from the real grades. As shown in Table 2, results demonstrated that the model was able to explain a significant amount of variation in the deviation of self-estimated exam grades from real exam grades.

In the last stage of the statistical analysis, a two-way analysis of variance was carried out to explore whether the deviation of self-estimated exam grade from the real grade may differ as a result of narcissism and neuroticism. Results indicated the significant main effect for narcissism $\left[F_{(1.57)}=10.35\right.$, $\left.p=0.002, \eta 2=0.15, \omega^{2}=0.88\right]$. In this respect, while high-narcissism individuals self-estimated exam 
grades deviated from the real grades $17.01 \%$, low-narcissistic individuals' self-estimated exam grades deviated from the real grades only $4.87 \%$. On the contrary, there was no main effect for neuroticism $\left[F_{(1.57)}=0.100, p=0.752, \eta 2=0.002, \omega^{2}=0.06\right]$. However, narcissism $\mathrm{x}$ neuroticism interaction effect was significant $\left[F_{(1.57)}=8.41, p=0.005, \eta 2=0.13, \omega^{2}=0.81\right]$.

\section{DISCUSSION}

The present study aimed to examine the effect of narcissism and neuroticism on physical education and sports teacher candidates' real and self-estimated exam grades. Results showed that narcissistic individuals estimated their exam grades approximately $17 \%$ higher than their real exam grades. Further, narcissistic personality was unrelated to real exam grades, which means that narcissism cannot be a predictor of success in an academic examination. On the other hand, non-narcissistic individuals were able to estimate their exam grades more accurately and realistically. Hence, their self-estimated exam grades deviated from the real exam grades only $4 \%$. This result provided support for the hypothesis that narcissism is associated with inflated self-estimated exam grade or academic success.

However, the data did not support the hypothesis regarding the relationship between neuroticism and real and self-estimated academic success. Neuroticism was unrelated to both real and self-estimated exam grades. Despite the lack of relationship between neuroticism and both exam grades, results of the two-way analysis variance demonstrated that interacting with narcissism; neuroticism may predict the deviation of self-estimated exam grades from the real grades.

The most exciting result of the present study, which reveals a lack of association between narcissism and performance provided support for previous studies investigating the same topic in different domains. For example, Gabriel et al. (1994) found no relationship between narcissism and performance in an intelligence test. Moreover, similar to the present results, Gabriel et al. demonstrated that narcissistic individuals might tend to overestimate their intelligence. Woodman et al. (2011) also provided strong support for the lack of association between narcissism and performance. Woodman et al.) further showed that the link between narcissism and performance might be depending on situational factors such as identifiability. The defining features of narcissism may provide a theoretical explanation for the question of why narcissistic individuals overestimate their own exam grades. In this respect, narcissistic individuals see themselves as special and unique individuals, having extraordinary abilities. Narcissistic individuals probably try to maintain a positive view of self by exaggerating their level of accomplishment (Gabriel et al.).

Despite the theoretical reasons to assume that neuroticism might be a debilitating factor for the success in an academic examination; data did not support this argument. Previous research investigating this association produced conflicting results. For example, Tok and Moralı (2009) did not find a relationship between neuroticism and overall academic success. On the other hand, Chamorro-Premuzic and Furnham (2003) found neuroticism to be slightly associated with exam grades. Although neuroticism was not associated with both real and self-estimated exam grades, neuroticism interacted with narcissism in predicting the deviation of the self-estimated exam grades from the real grades. Hence, these results provided preliminary support for the argument that in future studies, researchers may wish to take into account personality super factors for a better understanding of the influence of narcissism on academic success parameters.

\section{CONCLUSION}

The present study, together with previous studies cited above-provided evidence that both narcissism and neuroticism may not be a consistent predictor of the success in an academic examination. However, it seems that narcissistic individuals may be prone to overestimate their academic capabilities. Thus, narcissism may give rise to an unrealistic evaluation of individuals' own academic success in a particular examination.

\section{PRACTICAL APPLICATION}

These results may have some implications, especially for educational managers and as well as teachers. First, managers should be aware that narcissistic students may be prone to overestimate their academic success, which can give rise to essential conflicts between students and teachers. To avoid probable conflicts between teachers and students who are predisposed to overestimate their academic success, exams can be designed carefully and objectively. 


\section{REFERENCES}

American Psychiatric Association. (2000). Diagnostic and statistical manual of mental disorders (4th ed., text revision). Washington, DC: American Psychiatric Association.

Atay, S. (2009). NARSİST Kişilik Envanteri'nin Türkçe'ye Standardizasyonu. İktisadi ve İdari Bilimler Fakültesi Dergisi, 11(1), 1-16.

Barlow, M., Woodman, T. Gorgulu, R. \& Voyzey, R. (2016). Ironic effects of performance are worse for neurotics. Psychology of Sport and Exercise, 24, 27-37, doi:10.1016/j.psychsport.2015.12.005.

Chamorro-Premuzic, T., \& Furnham, A. (2003). Personality Traits and Academic Examination Performance. European Journal of Personality, 17(3), 237-250. https://doi.org/10.1002/per.473

Gabriel, M. T., Critelli, J. W., \& Ee, J. S. (1994). Narcissistic illusions in self-evaluations of intelligence and attractiveness. Journal of Personality, 62, 143-155.

Greenberger, E., Lessard, J., Chen, C., \& Farruggia, S. P. (2008). Self-entitled college students: Contributions of personality, parenting, and motivational factors. Journal of Youth and Adolescence, 37, 1193-1204.

John, O. P., \& Robins, R. W. (1994). Accuracy and bias in selfperception: Individual differences in selfenhancement and the role of narcissism. Journal of Personality \& Social Psychology, 66, 206219.

Miller, J. D., \& Campbell, W. K. (2008). Comparing clinical and social-personality conceptualizations of narcissism. Journal of Personality. Journal of Personality, 76(3), 449-476.

Millon, T., \& Davis, R. O. (1996). Disorders of personality: DSM-IV and beyond (2nd ed.). (John Wiley \& Sons., Ed.). Oxford, England.

Raskin, R. N., \& Terry, H. (1988). A principal-components analysis of the narcissistic personality inventory and further evidence of its construct validity. Journal of Personality \& Social Psychology, 54, 890-902.

Ridgell, S. D., \& Lounsbury, J. W. (2004). Predicting academic success: General intelligence," Big Five" personality traits, and work drive. College Student Journal, 38(4), 607-619.

Somer, O., Korkmaz, M., \& Tatar, A. (2004). Somer, O., Korkmaz, M., \& Tatar, A. (2004). Five-factor personality model from theory to application and five-factor personality inventory. Bornova/Izmir: Ege University Press. Five-factor personality model from theory to application and five-factor personality inventory.

Tatar A. (2005). Çok Boyutlu Kişilik Envanteri'nin Madde-Cevap Kurarmna Gore Kisa Formunun Geliştirilmesi ve Psikometrik ozelliklerinin incelenmesi. Ege Üniversitesi, Sosyal Bilimler Üniversitesi.

Tok, S., \& Morali, S. L. (2009). Trait Emotional Intelligence, The Big Five Personality Dimensions And Academic Success In Physical Education Teacher Candidates. Social Behavior and Personality, 37(7), 921-932. https://doi.org/http://dx.doi.org/10.2224/sbp.2009.37.7.921

Woodman, T., Roberts, R., Hardy, L., Callow, N., \& Rogers, C. H. (2011). There Is an "I" in TEAM: Narcissism and Social Loafing. Research Quarterly for Exercise and Sport, 82(2), 285-290. https://doi.org/10.1080/02701367.2011.10599756

\section{CITATION OF THIS ARTICLE}

Dal, N. (2019) The Effect of Narcissism and Neuroticism on Physical Education and Sports Teacher Candidates of Real and Self-Estimated Exam Grades. International Journal of Sport, Exercise \& Training Sciences - IJSETS, 5(3), 138-142. DOI: 10.18826/useeabd.592614 